\title{
High expression of Nectin-4 is associated with unfavorable prognosis in gastric cancer
}

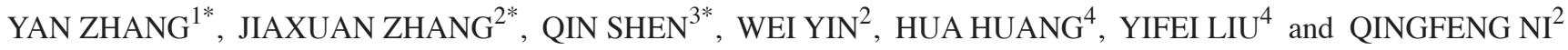 \\ Departments of ${ }^{1}$ Oncology and ${ }^{2}$ General Surgery, Affiliated Hospital of Nantong University; \\ ${ }^{3}$ Medical College, Nantong University; ${ }^{4}$ Department of Pathology, Affiliated Hospital of \\ Nantong University, Nantong, Jiangsu 226001, P.R. China
}

Received August 3, 2016; Accepted January 8, 2018

DOI: $10.3892 / \mathrm{ol} .2018 .8365$

\begin{abstract}
Nectins are $\mathrm{Ca}^{2+}$-independent immunoglobulin-like cell adhesion molecules that belong to a family of four members that function in a number of biological cellular activities. Nectin-4 is overexpressed in several types of human cancer; however, the functional and prognostic significance of Nectin-4 in gastric cancer (GC) remains unclear. In the present study, the reverse transcription-quantitative polymerase chain reaction and tissue microarray immunohistochemical analysis were used to investigate the expression of Nectin-4 in GC as well as its function in the prognosis of patients with GC. The results indicated that mRNA and protein expression of Nectin-4 were increased in tumor tissues compared with the matched non-tumor tissues. Expression of Nectin- 4 was closely associated with differentiation $(\mathrm{P}=0.004)$, primary tumor $(\mathrm{P}=0.001)$, lymph node metastasis $(\mathrm{P}<0.001)$ and tumor-node-metastasis $(\mathrm{TNM})$ stage $(\mathrm{P}<0.001)$. Positive Nectin-4 expression $(\mathrm{P}=0.001)$ and advanced TNM stage $(\mathrm{P}<0.001)$ were demonstrated to be associated with overall survival time in multivariate analyses. These results suggest that Nectin-4 may serve a significant function in GC and may serve as a novel clinic pathological biomarker and therapeutic target in GC.
\end{abstract}

Correspondence to: Professor Qingfeng Ni, Department of General Surgery, Affiliated Hospital of Nantong University, 20 Xisi Road, Nantong, Jiangsu 226001, P.R. China

E-mail: qfni19841116@sina.com

Professor Yifei Liu, Department of Pathology, Affiliated Hospital of Nantong University, 20 Xisi Road, Nantong, Jiangsu 226001, P.R. China

E-mail: bluefiime@qq.com

${ }^{*}$ Contributed equally

Key words: Nectin-4, gastric cancer, reverse transcriptionquantitative polymerase chain reaction, immunohistochemistry, prognosis

\section{Introduction}

Gastric cancer (GC) is one of the most common malignant tumors globally (1-4). In China, GC is the second leading cause of cancer-associated mortality (5). In spite of the decreasing incidence and mortality rate of $\mathrm{GC}$ among the Chinese population, 723,100/951,600 novel cases of GC resulted in mortality in 2012 (6). The treatment protocols available include surgery, chemotherapy, radiotherapy and molecular targeted therapy $(7,8)$. Nevertheless, the median survival remains $<12$ months and the 5-year survival rate is $\sim 25 \%$ as a result of tumor recurrence and metastasis (9). Therefore, identifying new prognostic biomarkers and therapeutic targets for GC is of high importance.

Nectin-4 is a member of the Nectin family of four $\mathrm{Ca}^{2+}$-independent immunoglobulin-like cell adhesion molecules and is involved in several functional processes, including cell adhesion, movement, proliferation, differentiation, polarization and survival (10-13). Nectin-4 is expressed specifically in the embryo and placenta, whereas Nectin-1-3 are identified in adult tissues $(14,15)$. Several studies have indicated that Nectin-4 is overexpressed in a variety of tumors and tumor cell lines (16-19). In human pancreatic cancer, Nectin-4 induced tumor proliferation, angiogenesis and indicated poor prognosis (20). High expression of Nectin-4 in hepatocellular carcinoma was associated with poor prognosis and was an independent prognostic marker for patients with HCC (21). Takano et al (22) reported that Nectin-4 was implicated in cell proliferation and growth of tumors via the Racl signaling pathway in human lung adenocarcinoma cells. In a different study, Nectin-4 regulated Rac-1 activity by activating the phosphoinositide 3-kinase (PI3K)/protein kinase B (AKT) signaling pathway to mediate cell proliferation and migration (23). However, to the best of our knowledge, the expression of Nectin-4, as well as its prognostic significance, has not been investigated in GC.

In the present study, Nectin-4 mRNA and protein expression were determined in GC tissues and adjacent non-tumorous tissues using the reverse transcription-quantitative polymerase chain reaction (RT-qPCR) and immunohistochemistry (IHC), its association with clinical parameters as well as its prognostic significance in patients with GC were determined. The results indicate that Nectin-4 may be a predictive biomarker for poor prognosis in patients with GC. 


\section{Materials and methods}

Tissue samples. A total of 20 pairs of fresh-frozen GC tissues and surrounding non-cancerous tissues were collected for RT-qPCR assay from the Department of Pathology at the Affiliated Hospital of Nantong University between January 2015 to June 2015. Additionally, between January 2010 and January 2015, 303 formalin-fixed paraffin-embedded tissues, including $212 \mathrm{GC}$ tumor samples and 91 adjacent normal tissues, were collected for immunohistochemistry from the Affiliated Hospital of Nantong University. Two pathologists (from the Affiliated Hospital of Nantong University) blinded to each other checked the grade [Tumor Node Metastasis (TNM) classification of malignant tumors, 7th edition, Union for International Cancer Control] (24) and histological type of all cases. The age range was between 22 and 84 years (median age, 55.3 years), and the samples were from 72 females and 140 males. The patients did not receive any prior treatment for their cancer. The Human Research Ethics Committee of Nantong University Affiliated Hospital approved the present study and all clinical methods applied, and all patients provided written informed consent prior to participation in this clinical trial and research.

RT-qPCR. Trizol ${ }^{\circledR}$ reagent (Thermo Fisher Scientific, Inc., Waltham, MA, USA) was used according to the manufacturer's protocol to extract total RNA from the samples, and RNA was reverse-transcribed into cDNA for amplification, using $5 \mathrm{x}$ Buffer $(1 \mu \mathrm{g})$, RT Enzyme Mix I $(2 \mu \mathrm{l})$, Oligo dT Prime $(0.5 \mu \mathrm{l})$, randon 6mers $(2 \mu \mathrm{l})$ and total RNA $(1 \mu \mathrm{g})$ and a temperature protocol of $37^{\circ} \mathrm{C}$ for $15 \mathrm{~min}, 85^{\circ} \mathrm{C}$ for $5 \mathrm{sec}$ and $4^{\circ} \mathrm{C}$ for $5 \mathrm{~min}$. Nectin- 4 primers used in qPCR were as follows: Forward primer 5'-CAAAATCTGTGGCACATTGG-3' and reverse primer 5'-GCTGACATGGCAGACGTAGA-3'. For qPCR, SYBR $^{\circledR}$ Premix Ex Taq ${ }^{\mathrm{TM}}$ reagent (Takara Biotechnology Co. Ltd., Dalian, China) was used, and thermo cycling conditions as follows: $95^{\circ} \mathrm{C}$ for $30 \mathrm{sec}, 95^{\circ} \mathrm{C}$ for $5 \mathrm{sec}$ and $60^{\circ} \mathrm{C}$ for $30 \mathrm{sec}$ maintained for 40 cycles. As an internal control, $\beta$-actin was amplified using a forward primer of 5'-AGAGCCTCGCCT TTGCCGATCC-3' and a reverse primer of 5'-CTGGGCCTC GTCGCCCACATA-3'. For quantification (25), StepOnePlus ${ }^{\mathrm{TM}}$ PCR (Applied Biosystems; Thermo Fisher Scientific, Inc.) was used. All procedures were repeated three times.

Tissue microarray (TMA) construction and IHC analysis. TMAs consisted of formalin-fixed GC tumor tissues $(\mathrm{n}=212)$ and paired normal tissues $(\mathrm{n}=91)$. TMAs were generated in the Department of Clinical Pathology of Nantong University Hospital (Jiangsu, China) using the Tissue Microarray System Quick-Ray (UT06; Unitma Co., Ltd., Seongnam, South Korea). Each core of the paraffin-recipient blocks was $2 \mathrm{~mm}$ in diameter and samples taken from paraffin-embedded tissue sections were arrayed in them. TMA specimens were sliced into $4-\mu \mathrm{m}$-thick sections and located on Superfrost glass microscope slides. IHC was performed as described previously (26). Subsequently, an antibody against Nectin-4 (1:100; cat no. Ab192033; Abcam, Cambridge, MA, USA) was incubated with the slides at $4^{\circ} \mathrm{C}$ overnight. Following 3 washes with PBS, the slides were incubated with fluorescein isothiocyanate-conjugated goat anti-rabbit IgG heavy and light

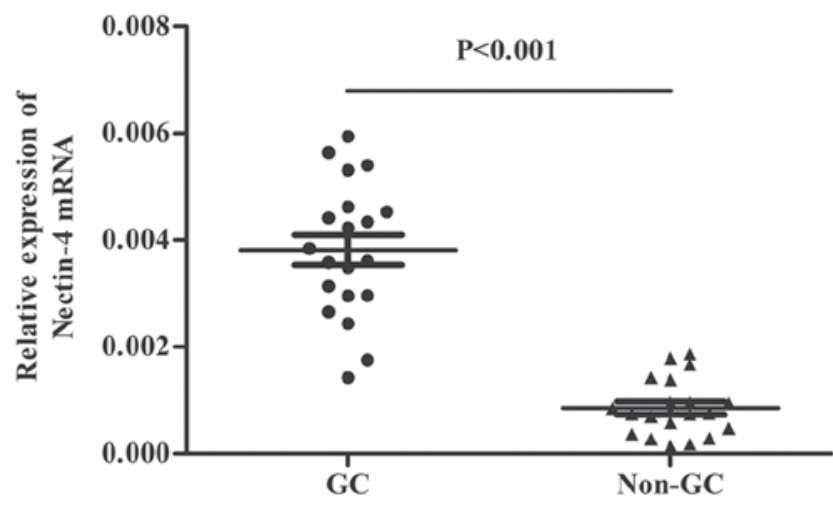

Figure 1. Expression of Nectin-4 mRNA in GC and matched tumor-adjacent tissues. Nectin-4 mRNA expression was evaluated using the reverse transcription-quantitative polymerase chain reaction in GC compared with normal tumor adjacent tissue. Nectin-4 mRNA level was significantly higher in GC samples $(0.0038 \pm 0.0012)$ compared with in matched adjacent non-cancerous samples $(0.0008 \pm 0.0005)$. $\mathrm{P}<0.001$, normalizing to $\beta$-actin mRNA. GC, gastric cancer.

chain (1:200; cat. no. ab97050; Abcam) secondary antibody at $37^{\circ} \mathrm{C}$ for $1 \mathrm{~h}$. The slides were then stained with $0.05 \%$ diaminobenzidine for $3 \mathrm{~min}$ at room temperature at a dilution of 1:20, and the nuclei were counterstained with $2 \%$ haemotoxylin (for 5-10 min at room temperature) for color rendering. The stained samples were visualized under a light microscope, and the percentage of Nectin-4-positive cells, and cell staining intensity (as described below) was calculated.

TMA-IHC data evaluation. IHC staining was analyzed by two independent pathologists, who had no knowledge of the present investigation or the clinicopathological data of each specimen. To evaluate the protein expression, the staining intensity was graded between 0 and 3 , as well as the percentage of cells stained (0-100). The staining intensity was designated negative (0), weakly positive (1), moderately positive (2) or strongly positive (3). The final score was calculated by multiplying the percentage of Nectin-4-positive cells and the staining intensity, with potential results ranging between 0 and 300 . The score was subsequently categorized into low expression and high expression based on a threshold value determined by the X-file software of the score (Rimm Laboratory at Yale University; http://www.tissuearray.org/rimmlab) as previously described (24). The threshold value for Nectin-4 was 70, and the final scores were classified into two groups: Low expression $(\leq 70)$ and high expression $(>70)$.

Statistical analysis. Differences between Nectin- 4 mRNA expression in fresh GC and matching tumor-adjacent tissues were analyzed using the Wilcoxon non-parametric signed-rank test. A Pearson $\chi^{2}$ test was applied to evaluate the associations of Nectin-4 expression with clinicopathological variables of patients with GC. The univariate Cox's regression model was used to determine factors with prognostic significance, and a multivariate Cox's regression model was used for further evaluation. $\mathrm{P}<0.05$ was considered to indicate a statistically significant difference. All statistical analyses were performed using SPSS software (version 20.0; IBM Corp., Armonk, NY, USA). 


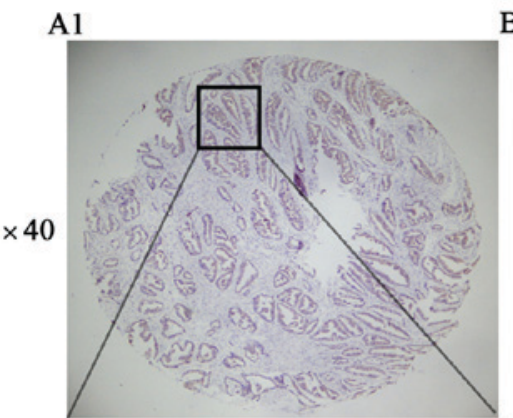

B1

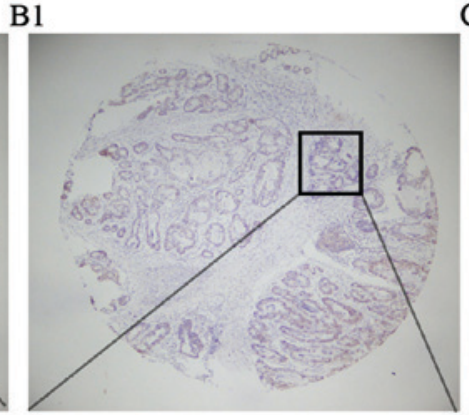

A2

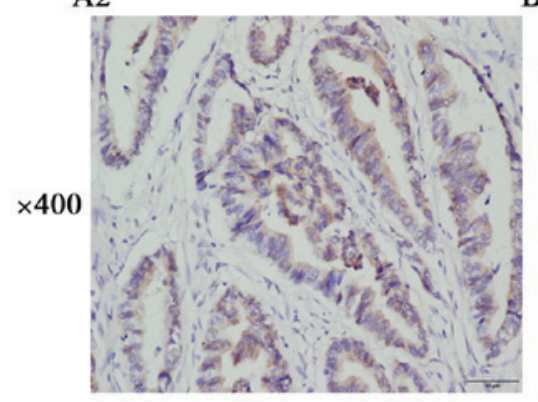

B2

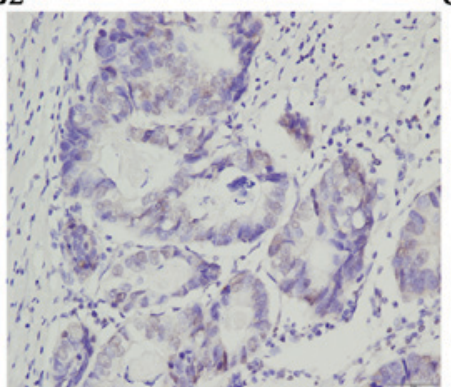

C1

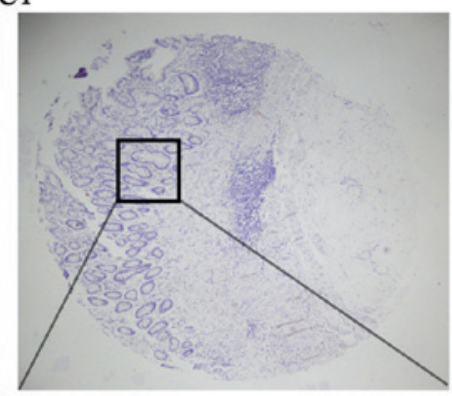

C2

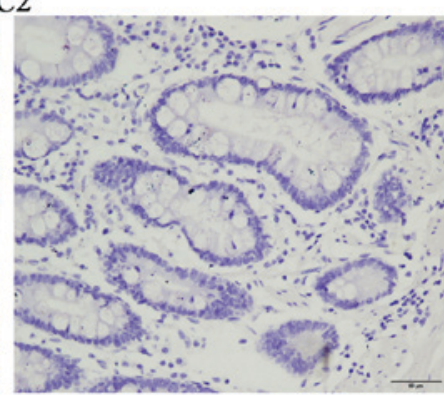

Figure 2. Representative Nectin-4 protein expression in GC and matched, peritumoral tissues. (A1, 2) Strong positive IHC staining of Nectin-4 in GC. (B1, 2) Positive expression of Nectin-4 in GC. (C1, 2) Peritumoral tissues, negative expression of Nectin-4 in GC. Magnification, x40 (A1, B1, C1), x400 (A2, B2, C2).

\section{Results}

Evaluation of Nectin-4 mRNA expression in GC using $R T$ - $q P C R$. RT-qPCR was employed to determine the relative expression of Nectin-4 mRNA which was isolated from $20 \mathrm{GC}$ tissues and matched tumor-adjacent normal tissue. It was identified that Nectin-4 mRNA expression was significantly higher in GC samples $(0.0038 \pm 0.0012)$ compared with the paired adjacent non-tumor samples $(0.0008 \pm 0.0005)$ $(\mathrm{P}<0.001$; Fig. 1).

Nectin-4 expression in GC tissues by IHC. To validate the results acquired from RT-qPCR, TMA-IHC was employed to evaluate Nectin-4 protein expression on $212 \mathrm{GC}$ tissues and 91 matched peritumoral tissues. In GC tissues, positive staining was mainly observed in the cell membrane and cytoplasm. High expression levels of Nectin-4 were detected in $60.4 \%(128 / 212)$ of GC tumors compared with only $15.4 \%$ $(14 / 91)$ of matched adjacent normal tissue samples $\left(\chi^{2}=51.76\right.$; $\mathrm{P}<0.001)$, which was consistent with the current RT-qPCR results (Fig. 2).

Association between Nectin-4 protein expression and clinicopathological parameters of patients with $G C$. The association between high Nectin-4 expression and different types of clinicopathological parameters of patients with GC is indicated in Table I. It was identified that high expression of Nectin-4 was notably associated with differentiation $(\mathrm{P}=0.004)$, primary tumor $(\mathrm{P}=0.001)$, lymph node metastasis $(\mathrm{P}<0.001)$ and $T N M$ stage $(\mathrm{P}<0.001)$. However, no association was observed between Nectin-4 and other clinical features, including sex, age, tumor location, tumor size and preoperative carcinoembryonic antigen level (27) (Table I), distant metastasis (M) occurred in only 10 cases, therefore its association with Nectin-4 was not evaluated.
Survival analysis. A univariate analysis was used to investigate all relevant features, and it was identified that high Nectin-4 expression $(\mathrm{P}<0.001)$, along with tumor size $(\mathrm{P}<0.001)$, tumor differentiation $(\mathrm{P}<0.001), \mathrm{T}(\mathrm{P}<0.001), \mathrm{N}(\mathrm{P}<0.001)$ and tumor TNM stage $(\mathrm{P}<0.001)$, was markedly associated with the survival of patients (Table II). Multivariate regression analysis was subsequently employed to further confirm that Nectin-4 expression $(\mathrm{P}=0.002)$ and tumor $\mathrm{TNM}$ stage $(\mathrm{P}<0.001)$ were independent prognostic indicators in GC (Table II). Kaplan-Meier survival curves revealed that patients with GC with high Nectin-4 expression, large tumor size ( $\geq 3 \mathrm{~cm})$, low-differentiated tumors and advanced TNM stage had a significantly poorer prognosis $(\mathrm{P}<0.001$; Fig. 3$)$.

\section{Discussion}

In the present study, RT-qPCR analysis was used to compare the mRNA expression of Nectin-4 in GC tissues with matched normal tissues. The result identified a marked increase in tumor tissues, which as consistent with previous studies (19-23). TMA-IHC was subsequently performed to further validate this result, and it was identified that Nectin-4 protein was similarly highly expressed in GC tumorous tissues when compared with adjacent non-tumorous tissues. High protein expression of Nectin-4 in GC was associated with certain pathological and clinical features including differentiation degree, primary tumor, lymph node metastasis and TNM stage. Univariate analysis was employed to investigate the association between clinicopathological characteristics including Nectin-4 and overall survival of patients with GC. The result revealed that Nectin-4 expression, tumor size, tumor differentiation, T, $\mathrm{N}$ and tumor TNM stage had a negative association with the overall 5-year survival rate in GC. Multivariate analysis further indicated that Nectin-4 expression as well as TNM stage independently predicted adverse outcomes of patients 
Table I. Association of Nectin-4 expression in tumorous tissues with clinicopathological characteristics in patients with gastric cancer.

\begin{tabular}{|c|c|c|c|c|c|}
\hline \multirow{2}{*}{$\begin{array}{l}\text { Clinicopathological } \\
\text { characteristic }\end{array}$} & \multirow[b]{2}{*}{$\mathrm{n}$} & \multicolumn{4}{|c|}{ Nectin-4 } \\
\hline & & Low or no expression, $\mathrm{n}(\%)$ & High expression, $\mathrm{n}(\%)$ & Pearson $\chi^{2}$ & P-value \\
\hline Total & 212 & $84(39.62)$ & $128(60.38)$ & & \\
\hline Sex & & & & 1.803 & 0.179 \\
\hline Male & 140 & $60(42.86)$ & $80(57.14)$ & & \\
\hline Female & 72 & $24(33.33)$ & $48(66.67)$ & & \\
\hline Age at diagnosis, years & & & & 0.016 & 0.898 \\
\hline$\leq 60$ & 92 & $36(39.13)$ & $56(60.87)$ & & \\
\hline$>60$ & 120 & $48(40.00)$ & $72(60.00)$ & & \\
\hline Tumor size, $\mathrm{cm}$ & & & & 3.441 & 0.064 \\
\hline$<3$ & 63 & $31(49.21)$ & $32(50.70)$ & & \\
\hline$\geq 3$ & 149 & $53(35.57)$ & $96(65.30)$ & & \\
\hline Location & & & & 1.816 & 0.403 \\
\hline Lower & 140 & $58(41.43)$ & $82(58.57)$ & & \\
\hline Middle & 45 & $14(31.11)$ & $31(68.89)$ & & \\
\hline Upper & 27 & $12(44.44)$ & $15(55.56)$ & & \\
\hline Differentiation & & & & 8.408 & $0.004^{\mathrm{a}}$ \\
\hline Low grade & 126 & $40(31.75)$ & $86(68.25)$ & & \\
\hline Middle and high grade & 70 & $37(52.86)$ & $33(47.14)$ & & \\
\hline Other & 16 & 7 & 9 & & \\
\hline Primary tumor & & & & 14.826 & $0.001^{\mathrm{a}}$ \\
\hline $\mathrm{T} 1$ & 51 & 27 (52.94) & $24(47.06)$ & & \\
\hline $\mathrm{T} 2$ & 41 & $23(56.10)$ & $18(43.90)$ & & \\
\hline $\mathrm{T} 3+\mathrm{T} 4$ & 120 & $34(28.33)$ & $86(71.67)$ & & \\
\hline Lymph node metastasis & & & & 18.544 & $<0.001^{\mathrm{a}}$ \\
\hline $\mathrm{N}_{0}$ & 103 & $55(53.40)$ & $48(46.60)$ & & \\
\hline $\mathrm{N}_{1}$ & 31 & $12(38.71)$ & $19(61.29)$ & & \\
\hline $\mathrm{N}_{2}+\mathrm{N}_{3}$ & 78 & $17(21.79)$ & $61(78.21)$ & & \\
\hline Stage grouping with TNM & & & & 32.749 & $<0.001^{\mathrm{a}}$ \\
\hline Stage I & 76 & $43(56.58)$ & $33(43.42)$ & & \\
\hline Stage II & 42 & $24(57.14)$ & $18(42.86)$ & & \\
\hline Stage III+IV & 94 & $17(18.09)$ & $77(81.91)$ & & \\
\hline Preoperative CEA, ng/ml & & & & 0.421 & 0.517 \\
\hline$\leq 5$ & 159 & $65(40.88)$ & 94 (59.12) & & \\
\hline$>5$ & 53 & $19(35.85)$ & $34(64.15)$ & & \\
\hline
\end{tabular}

${ }^{\mathrm{a}} \mathrm{P}<0.05$. Others: Mucinous carcinoma, 7 cases; adenosquamous carcinoma, 3 cases; signet ring cell carcinoma, 6 cases. TNM, tumor-node-metastasis; CEA, carcinoembryonic antigen; T1, Lamina propria, submucosa; T2, Muscularis propria; T3, Subserosa; T4, Perforates serosa and adjacent structures; $\mathrm{N}_{0}$ No regional lymph nodemetastasis; $\mathrm{N}_{1,1}$ to 2 nodes; $\mathrm{N}_{2}, 3$ to 6 nodes; $\mathrm{N}_{3,7-16}$ or more.

with GC. Kaplan-Meier analysis provided a visual representation that the lifetime of patients with low Nectin-4 expression was notably longer than that of patients with high expression.

As aforementioned, previous in vitro and in vivo evidence suggested the function of Nectin-4 in a number of tumors as a carcinogenic factor, which was consistent with results of the present study $(19,22,23)$. In gallbladder carcinoma, ectopic expression of Nectin-4 had been demonstrated to be associated with cell proliferation, movement ability and anchorage-independent growth in in vitro experiments and a mouse model (23). Takano et al (22) reported that Nectin-4 was highly associated with unfavorable clinical outcomes in non-small cell lung cancer, and increased expression of Nectin-4 was able to promote the formation of lamellipodia and increase the invasive ability of cancer cells through the Rac1 signaling pathway, and the proliferative ability of tumor cells silenced with siRNA of Nectin-4 was significantly decreased. Additionally, nectin-4, together with cancer antigen 
Table II. Univariate and multivariate analysis of prognostic factors of 5-year overall survival in patients with gastric cancer.

\begin{tabular}{|c|c|c|c|c|c|c|}
\hline \multirow[b]{2}{*}{ Characteristic } & \multicolumn{3}{|c|}{ Univariate analysis } & \multicolumn{3}{|c|}{ Multivariate analysis } \\
\hline & HR & P-value & $95 \% \mathrm{CI}$ & HR & $\mathrm{P}$-value & $95 \% \mathrm{CI}$ \\
\hline $\begin{array}{l}\text { Nectin-4 expression } \\
\text { High vs. low and none }\end{array}$ & 3.815 & $<0.001^{\mathrm{a}}$ & $2.243-6.490$ & 2.402 & $0.002^{\mathrm{a}}$ & $1.364-4.232$ \\
\hline $\begin{array}{l}\text { Sex } \\
\text { Male vs. female }\end{array}$ & 0.825 & 0.387 & $0.533-1.276$ & & & \\
\hline $\begin{array}{l}\text { Age, years } \\
\leq 60 \text { vs. }>60\end{array}$ & 1.033 & 0.881 & $0.675-1.580$ & & & \\
\hline Location & 0.814 & 0.141 & $0.619-1.070$ & & & \\
\hline Lower vs. middle vs. upper & & & & & & \\
\hline $\begin{array}{l}\text { Tumor size, } \mathrm{cm} \\
<3 \text { vs. } \geq 3\end{array}$ & 3.810 & $<0.001^{\mathrm{a}}$ & $2.023-7.179$ & 1.638 & 0.151 & $0.835-3.214$ \\
\hline $\begin{array}{l}\text { Differentiation } \\
\text { Low vs. middle and high grade vs. others }\end{array}$ & 0.375 & $<0.001^{\mathrm{a}}$ & $0.220-0.640$ & 0.749 & 0.323 & $0.422-1.329$ \\
\hline $\begin{array}{l}\text { Primary tumor } \\
\mathrm{T} 1 \mathrm{vs.} \mathrm{T} 2 \mathrm{vs.} \mathrm{T} 3+\mathrm{T} 4\end{array}$ & 2.768 & $<0.001^{\mathrm{a}}$ & $1.913-4.006$ & & & \\
\hline $\begin{array}{l}\text { Lymph node metastasis } \\
\mathrm{N}_{0} \text { vs. } \mathrm{N}_{1} \text { vs. } \mathrm{N}_{2}+\mathrm{N}_{3}\end{array}$ & 2.224 & $<0.001^{\mathrm{a}}$ & $1.850-2.674$ & & & \\
\hline $\begin{array}{l}\text { TNM stage } \\
\text { I vs. II vs. III+IV }\end{array}$ & 3.660 & $<0.001^{\mathrm{a}}$ & $2.589-5.172$ & 2.442 & $<0.001^{\mathrm{a}}$ & $1.651-3.612$ \\
\hline $\begin{array}{l}\text { Preoperative CEA, } \mathrm{ng} / \mathrm{ml} \\
\leq 5 \text { vs. }>5\end{array}$ & 1.203 & 0.441 & $0.752-1.925$ & & & \\
\hline
\end{tabular}

${ }^{\text {aP }}<0$.05. Others: Mucinous carcinoma, 7 cases; adeno-squamous carcinoma, 3 cases; signetring cell carcinoma, 6 cases. TNM,tumor-node-metastasis; CEA, carcinoembryonic antigen; CI, confidence interval; T1, Lamina propria, submucosa; T2, Muscularis propria; T3, Subserosa; T4, Perforates serosa and adjacent structures; $\mathrm{N}_{0}$ No regional lymph nodemetastasis; $\mathrm{N}_{1}, 1$ to 2 nodes; $\mathrm{N}_{2}, 3$ to 6 nodes; $\mathrm{N}_{3,}$, -16 or more.

125 , may help to make a distinction between benign gynecological diseases and ovarian cancer (19).

Rac1 signaling is involved in in tumor growth and progression of numerous types of cancer, and a number of functions in the progression of cancer, including proliferation, differentiation, migration, invasion, survival and cancer metastasis (28-30). Rac1 signaling is necessary for the extension of protrusions, including the formation of lamellipodia, which is crucial for cell-cell adherence $(31,32)$. Cell-cell adhesive processes are important for cancer progression (33). Nectin family members are homophilic and heterophilic cell adhesion molecules that bind afadin scaffold molecule, an actin filament (F-actin)-binding protein through their cytoplasmic tails and associate with the actin cytoskeleton $(33,34)$. Nectins serve critical functions in cellular activities including movement, differentiation, polarization and the entry of viruses, in cooperation with other cell adhesion molecules and cell-surface membrane receptors $(10,13,35,36)$. Nectin-4 belongs to the family of cell adhesion molecules that regulate the formation of adherence functions, and Nectin-4 is different from the other the Nectin family members owing to its distinct distribution, in that it is expressed specifically in the embryo and placenta as opposed to adult tisues $(14,15)$. Overexpression of Nectin-4 has been identified to be an essential contributor to cell proliferation and highly malignant tumor phenotypes and is known to serve a function as a significant mediator of the Rac1 signaling pathway (22). Activation of Rac1 signaling enables Nectin-4 to enhance the lamellipodia formation, cellular proliferation and migration of the cell (37). Previous studies have also demonstrated that the Rac1 signaling pathway is mainly modulated by the PI3K/AKT and mitogen-activated protein kinase/extracellular-signal-regulated kinase (ERK) kinase (MEK)/ERK signaling pathways in several types of human tumor (38-40). Zhang et al (23) also demonstrated that Rac1 was a downstream target of the PI3K/AKT pathway and demonstrated that this pathway cooperated with Nectin-4 and Rac1 to mediate cell proliferation and migration during tumor progression; furthermore, no association was identified between Nectin-4 and the MEK/ERK signaling pathway (23). Collectively, these studies suggested that Nectin-4 exerted oncogenic properties and may be a candidate for targeted therapy in certain types of human cancer.

There are several limitations of the present study. The expression of Nectin-4 in patients with GC was studied retrospectively, therefore whether Nectin-4 is the main promoting factor of GC progression or a consequence of GC development remains uncertain, and additional study is required to resolve the precise nature of the association. Furthermore, TMA-IHC was employed to evaluate Nectin-4 protein expression. The 

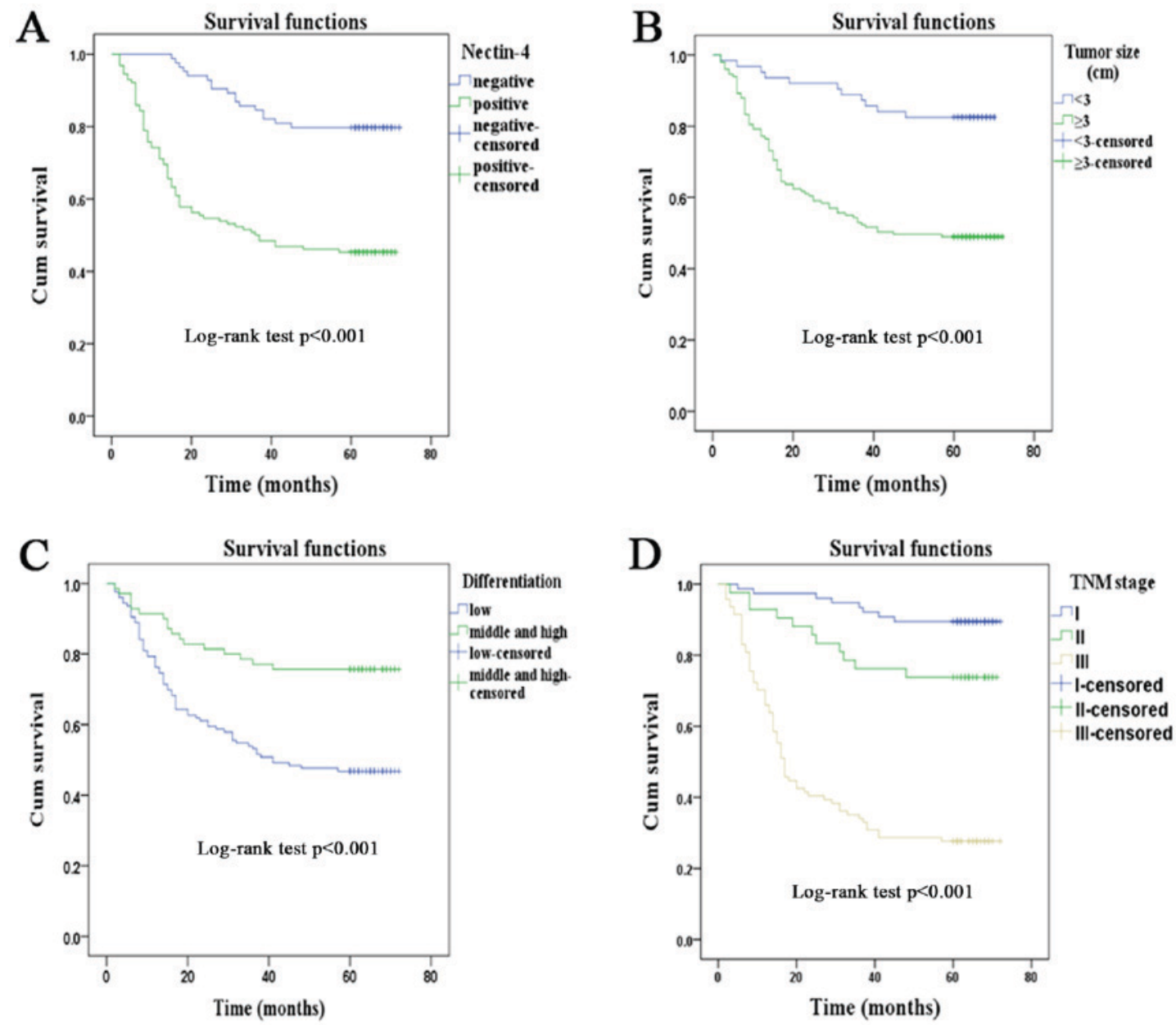

Figure 3. Survival curves of patients with GC by the Kaplan-Meier method and the log-rank test. (A) The patients with high cytoplasmic Nectin-4 expression exhibited significantly lower overall survival compared with the patients with no or low cytoplasmic Nectin-4 expression. (B) The patients with tumor size $\geq 3 \mathrm{~cm}$ had significantly lower overall survival than the patients with tumor size $<3 \mathrm{~cm}$. (C) The patients with poorly differentiated tumors exhibited significantly lower overall survival compared with the patients with moderately to highly differentiated tumors. (D) The patients with advanced TNM stage had significantly lower overall survival than the patients with early TNM stage. Cum, cumulative; GC, gastric cancer.

results were subjective and semiquantitative, therefore additional methods are required to validate the expression level of Nectin-4 in cancer tissues and cells. Finally, in vitro and in vivo studies were not performed to identify the underlying molecular mechanisms of Nectin-4 expression in GC.

The results of the present study suggested that expression of Nectin-4 was higher in GC tissues and was significantly associated with poorer outcome. Therefore, Nectin-4 was able to serve as a novel marker, and is a promising target to evaluate the prognosis of patients with GC. The results of the present study enrich current knowledge of Nectin-4 in the occurrence and development of GC. Further study should be carried out to explore the underlying molecular mechanism of action of this molecule in GC development. In conclusion, the present study provides rationale to further investigation into the involvement of Nectin-4 in GC development in addition to Nectin-4 as a potential prognostic marker and therapeutic target in GC.

\section{Funding}

The present study was supported by the National Natural Science Foundations for Young Scientists of China (grant no. 81502053).

\section{Availability of data and materials}

The datasets generated and analyzed in the present study are included in this published article.

\section{Authors' contributions}

YZ, YL and QN conceived and designed the experiments. JZ, QS and HH performed the experiments. QS and WY performed statistical analysis and data interpretation. YZ wrote the manuscript.

\section{Ethics and consent to participate}

The Human Research Ethics Committee of Nantong University Affiliated Hospital approved the present study and all clinical methods applied, and all patients provided written informed consent prior to participation in this clinical trial and research.

\section{Consent for publication}

All patients provided consent for publication. 


\section{Competing interests}

The authors declare that they have no competing interests.

\section{References}

1. Hartgrink HH, Jansen EP, van Grieken NC and van de Velde CJ: Gastric cancer. Lancet 374: 477-490, 2009.

2. Jemal A, Bray F, Center MM, Ferlay J, Ward E and Forman D: Global cancer statistics. CA Cancer J Clin 61: 69-90, 2011.

3. Goggins WB and Wong GK: Poor survival for US Pacific Islander cancer patients: Evidence from the surveillance, epidemiology, and end results database: 1991 to 2004. J Clin Oncol 25: 5738-5741, 2007.

4. Jemal A, Siegel R, Ward E, Hao Y, Xu J, Murray T and Thun MJ: Cancer statistics, 2008. CA Cancer J Clin 58: 71-96, 2008.

5. Lin Y, Ueda J, Kikuchi S, Totsuka Y, Wei WQ, Qiao YL and Inoue M: Comparative epidemiology of gastric cancer between Japan and China. World J Gastroenterol 17: 4421-4428, 2011.

6. Torre LA, Bray F, Siegel RL, Ferlay J, Lortet-Tieulent J and Jemal A Global cancer statistics, 2012. CA Cancer J Clin 65: 87-108, 2015.

7. Choi YY, Noh SH and Cheong JH: Evolution of gastric cancer treatment: From the golden age of surgery to an era of precision medicine. Yonsei Med J 56: 1177-1185, 2015.

8. Peng P, Wu W, Zhao J, Song S, Wang X, Jia D, Shao M, Zhang M, Li L, Wang L, et al: Decreased expression of Calpain-9 predicts unfavorable prognosis in patients with gastric cancer. Sci Rep 6 : 29604, 2016.

9. Garrido M, Fonseca PJ, Vieitez JM, Frunza M and Lacave AJ: Challenges in first line chemotherapy and targeted therapy in advanced gastric cancer. Expert Rev Anticancer Ther 14 887-900, 2014.

10. Takai Y, Ikeda W, Ogita H and Rikitake Y: The immunoglobulin-like cell adhesion molecule nectin and its associated protein afadin. Annu Rev Cell Dev Biol 24: 309-342, 2008.

11. Yasumi M, Shimizu K, Honda T, Takeuchi M and Takai Y: Role of each immunoglobulin-like loop of nectin for its cell-cell adhesion activity. Biochem Biophys Res Commun 302: 61-66, 2003.

12. Nakanishi $\mathrm{H}$ and Takai $\mathrm{Y}$ : Roles of nectins in cell adhesion, migration and polarization. Biol Chem 385: 885-892, 2004.

13. Takai Y, Miyoshi J, Ikeda W and Ogita $\mathrm{H}$ : Nectins and nectin-like molecules: Roles in contact inhibition of cell movement and proliferation. Nat Rev Mol Cell Biol 9: 603-615, 2008.

14. Reymond N, Fabre S, Lecocq E, Adelaïde J, Dubreuil P and Lopez M: Nectin4/PRR4, a new afadin-associated member of the nectin family that trans-interacts with nectin1/PRR1 through V domain interaction. J Biol Chem 276: 43205-43215, 2001.

15. Fabre S, Reymond N, Cocchi F, Menotti L, Dubreuil P, Campadelli-Fiume G and Lopez M: Prominent role of the Ig-like $\mathrm{V}$ domain in trans-interactions of nectins. Nectin3 and nectin 4 bind to the predicted C-C'-C'-D beta-strands of the nectin1 V domain. J Biol Chem 277: 27006-27013, 2002.

16. Fabre-Lafay S, Monville F, Garrido-Urbani S, Berruyer-Pouyet C, Ginestier C, Reymond N, Finetti P, Sauvan R, Adélaïde J, Geneix J,et al: Nectin-4 is a new histological and serological tumor associated marker for breast cancer. BMC Cancer 7: 73, 2007.

17. Fabre-Lafay S, Garrido-Urbani S, Reymond N, Gonçalves A, Dubreuil P and Lopez M: Nectin-4, a new serological breast cancer marker, is a substrate for tumor necrosis factor-alpha-converting enzyme (TACE)/ADAM-17. J Biol Chem 280: 19543-19550, 2005.

18. Athanassiadou AM, Patsouris E, Tsipis A, Gonidi M and Athanassiadou P: The significance of Survivin and Nectin-4 expression in the prognosis of breast carcinoma. Folia Histochem Cytobiol 49: 26-33, 2011.

19. Derycke MS, Pambuccian SE, Gilks CB, Kalloger SE, Ghidouche A, Lopez M, Bliss RL, Geller MA, Argenta PA, Harrington KM and Skubitz AP: Nectin 4 overexpression in ovarian cancer tissues and serum: Potential role as a serum biomarker. Am J Clin Pathol 134: 835-845, 2010.

20. Nishiwada S, Sho M, Yasuda S, Shimada K, Yamato I, Akahori T, Kinoshita S, Nagai M, Konishi N and Nakajima Y: Nectin-4 expression contributes to tumor proliferation, angiogenesis and patient prognosis in human pancreatic cancer. J Exp Clin Cancer Res 34: 30, 2015.
21. Ma J, Sheng Z, Lv Y, Liu W, Yao Q, Pan T, Xu Z, Zhang C and Xu G: Expression and clinical significance of Nectin-4 in hepatocellular carcinoma. Onco Targets Ther 9: 183-190, 2016.

22. Takano A, Ishikawa N, Nishino R, Masuda K, Yasui W, Inai K, Nishimura H, Ito H, Nakayama H, Miyagi Y, et al: Identification of nectin-4 oncoprotein as a diagnostic and therapeutic target for lung cancer. Cancer Res 69: 6694-6703, 2009.

23. Zhang Y, Liu S, Wang L, Wu Y, Hao J, Wang Z, Lu W, Wang XA, Zhang F, Cao Y, et al: A novel PI3K/AKT signaling axis mediates Nectin-4-induced gallbladder cancer cell proliferation, metastasis and tumor growth. Cancer Lett 375: 179-189, 2016.

24. Jun KH, Lee JS, Kim JH, Kim JJ, Chin HM and Park SM: The rationality of $\mathrm{N} 3$ classification in the 7th edition of the International Union Against Cancer TNM staging system for gastric adenocarcinomas: A case-control study. Int J Surg 12: 893-896, 2014.

25. Livak KJ and Schmittgen TD: Analysis of relative gene expression data using real-time quantitative PCR and the 2(-Delta Delta C(T)) method. Methods 25: 402-408, 2001.

26. Ni S, Xu L, Huang J, Feng J, Zhu H, Wang G and Wang X: Increased ZO-1 expression predicts valuable prognosis in non-small cell lung cancer. Int J Clin Exp Pathol 6: 2887-2895, 2013.

27. Qin HF, Qu LL, Liu H, Wang SS and Gao HJ: Serum CEA level change and its significance before and after Gefitinib therapy on patients with advanced non-small cell lung cancer. Asian Pac J Cancer Prev 14: 4205-4208, 2013.

28. Wang Y, Chen Y, Wu M, Lan T, Wu Y, Li Y and Qian H: Type II cyclic guanosine monophosphate-dependent protein kinase inhibits Rac1 activation in gastric cancer cells. Oncol Lett 10: 502-508, 2015.

29. Zhu G, Fan Z, Ding M, Zhang H, Mu L, Ding Y, Zhang Y, Jia B, Chen L, Chang Z and Wu W: An EGFR/PI3K/AKT axis promotes accumulation of the Rac1-GEF Tiam1 that is critical in EGFR-driven tumorigenesis. Oncogene 34: 5971-5982, 2015.

30. Bousquet E, Calvayrac O, Mazières J, Lajoie-Mazenc I, Boubekeur N, Favre G and Pradines A: RhoB loss induces Rac1-dependent mesenchymal cell invasion in lung cells through PP2A inhibition. Oncogene 35: 1760-1769, 2016.

31. Jaffe AB and Hall A: Rho GTPases in transformation and metastasis. Adv Cancer Res 84: 57-80, 2002.

32. Takai Y, Sasaki T and Matozaki T: Small GTP-binding proteins. Physiol Rev 81: 153-208, 2001.

33. Samanta D and Almo SC: Nectin family of cell-adhesion molecules: Structural and molecular aspects of function and specificity. Cell Mol Life Sci 72: 645-658, 2015.

34. Sakisaka T, Ikeda W, Ogita H, Fujita N and Takai Y: The roles of nectins in cell adhesions: Cooperation with other cell adhesion molecules and growth factor receptors. Curr Opin Cell Biol 19: 593-602, 2007.

35. Rikitake Y, Mandai $\mathrm{K}$ and Takai Y: The role of nectins in different types of cell-cell adhesion. J Cell Sci 125: 3713-3722, 2012.

36. Fuchs A and Colonna M: The role of NK cell recognition of nectin and nectin-like proteins in tumor immunosurveillance. Semin Cancer Biol 16: 359-366, 2006.

37. Fortugno P, Josselin E, Tsiakas K, Agolini E, Cestra G, Teson M, Santer R, Castiglia D, Novelli G, Dallapiccola B, et al: Nectin-4 mutations causing ectodermal dysplasia with syndactyly perturb the racl pathway and the kinetics of adherens junction formation. J Invest Dermatol 134: 2146-2153, 2014.

38. Henderson V, Smith B, Burton LJ, Randle D, Morris M and Odero-Marah VA: Snail promotes cell migration through PI3K/AKT-dependent Rac1 activation as well as PI3K/AKT-independent pathways during prostate cancer progression. Cell Adh Migr 9: 255-264, 2015.

39. Vial E, Sahai E and Marshall CJ: ERK-MAPK signaling coordinately regulates activity of Rac1 and RhoA for tumor cell motility. Cancer Cell 4: 67-79, 2003.

40. Ray RM, Vaidya RJ and Johnson LR: MEK/ERK regulates adherens junctions and migration through Rac1. Cell Motil Cytoskeleton 64: 143-156, 2007. 